\title{
The Influence of Work Ability, Work Ethos and Work Environment on Employee Performance at Garment Industries in Jombang Indonesia
}

\author{
Novi Kurniawati1 ${ }^{1}$ Siti Mujanah² \\ 1,2 Faculty of Economics and Business University of 17 August 1945 Surabaya \\ e-mail: novitanov29@gmail.com ${ }^{1}$, sitimujanah@untag-sby.ac.id ${ }^{2}$
}

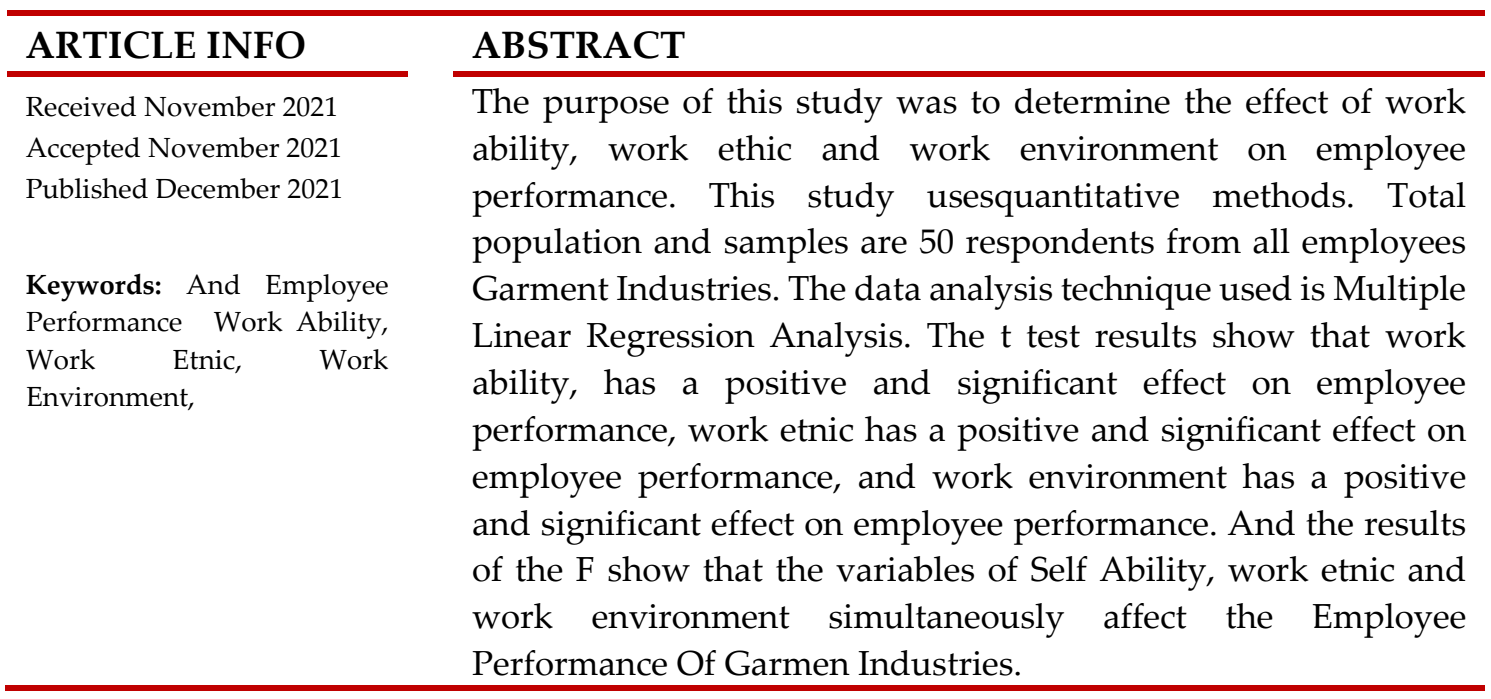

\section{Introduction}

Human resources play an important role in an organization or in a company. Labor have a factor in encouraging the progress of an organization or company. The potential that exists in quality human resources in a company will produce an optimal activity, so as to increase effectiveness and efficiency in a company to spur competitiveness [1]. Therefore, every organization needs quality human resources to achieve the goals that have been planned by the company. According to [2], human resource management is a planning, organizing, coordinating, implementing, and supervising procurement, development, remuneration, integration, and separation of workers in order to achieve organizational goals. The company's goals are said to be achievable not only depending on modern equipment, adequate facilities and infrastructure, but more depending on human resources who carry out the work [3].

The achievement of an organization is strongly influenced by the individual performance of its employees [4]. Every company organization must always spur the performance of its employees in the hope of achieving harmony in every part of the company, so that the expected goals are achieved [5]. Employee performance in a company can be influenced by several factors, including work ability, an organization can develop and survive, if supported by employees who are competent in their respective fields [6]. The ability of employees who are adjusted to the field of work required by the organization will be able to produce outstanding employee performance. 
Ability is the current capacity of individuals to perform various tasks in a job [7]. Overall abilities can be grouped into two categories, namely intellectual abilities and physical abilities. In addition to work ability, another factor that becomes an obstacle is work ethic [8]. Work ethic is an attitude towards work, so that a good work ethic will also result in good performance and will certainly have a significant effect on the progress of the company [9]. Employees who have a work ethic in their work are able to increase their organizational commitment [10]. Work ethic is very dominant for the success of one's work to the fullest, in the sense that the higher the work ethic of the employee, the higher the employee's performance [11].

According to [12], the work environment is a place for a number of groups in which there are several supporting facilities to achieve company goals in accordance with the company's vision and mission. [13] states that the conditions of a good work environment, if humans can carry out their work activities optimally, are healthy, safe, and comfortable [14]. The suitability of the work environment can be felt in the long term, while a poor work environment can change more labor and time, and does not support obtaining an efficient work system design [15]. Thus, the work environment is an activity environment in which employees perform work that can affect the achievement of organizational goals and create comfort in carrying out their duties [16].

The first thing that must be attempted to improve employee performance is to ensure that employees can carry out their duties in conditions that meet the requirements, so that they can carry out their duties without going through tensions, or in other words the organization must provide a good work environment for its employees [17]. As a result, in the long term furthermore, an unfavorable Working Condition can demand more manpower and time and does not support obtaining an efficient work system design [18].

The company's success is not only achieved by implementing a business plan but must be supported by the company's human resources. So it is a complex force where employee performance has direct consequences for the company [19]. If the human resources in the company have achieved their goals, it can be said that the company has the power to compete with other companies [20] [21]. Seeing some of the phenomena above, the problems in this study can be formulated whether work ability, work ethic and work environment affect employee performance at the Garment Industries.

\section{Research Methods}

The research in this thesis uses quantitative research. Quantitative research is a systematic scientific study of the parts and phenomena and the causality of their relationships. Quantitative research is one type of research whose specifications are systematic, planned and clearly structured from the beginning to the research design. Most quantitative research is carried out using statistical methods used to collect quantitative data from research studies.

The population of this study were all employees of the Garment Industries, totaling 50 employees. The method of determining the number of samples is carried out using saturated sampling. The number of samples taken from the Garment Industries is all employees, totaling 50 respondents. 
Data analysis method: In the research, the data analysis method uses Instrument Test which includes Validity Test and Reliability Test, Classical Assumption Test which includes Normality Test, Multicollinearity Test and Heteroscedasticity Test and uses Multiple Linear Regression Analysis. As for the hypothesis testing, this study uses the $t$ test to determine the effect partially and the $\mathrm{F}$ test to determine the effect simultaneously. The results of the validity test of each 1 item of questions on the variables Work Ability (X1), Work Ethic (X2), Work Environment (X3) and Employee Performance (Y) indicate that the value of $r$ count is greater than the $r$ table, so that every 1 item questions on each variable declared valid. Likewise, the reliability test results show that Cronbach's Alpha Value on Recruitment (X1), Workload (X2), Facilities (X3) and Employee Performance (Y) variables is greater than 0.60 so it can be concluded that all research variables are declared reliable.

\section{Result and Discussion}

Literature review:

a. Work Ability

Workability is the result of work achieved by someone who carries out the tasks assigned to him based on skills, experience and sincerity, and time [1]. Ability is one of the elements related to knowledge or qualifications obtained from education, training, or experience [22]. Ability is also a trait that is innate or learned that allows a person to complete a task the ability to demonstrate his potential ability to perform a task or job [23]. Workability can also be interpreted as one of the elements in maturity related to knowledge or skills obtained from education, training, or experience [6]. Workability can be measured through 2 (two) dimensions, namely physical ability and intellectual ability [10] [15].

According to [16], states that the company needs to develop the ability of employees to work better so that each employee can produce something that is directly related to the company's targets, because with adequate abilities, employees can carry out their work well. Employees who have adequate skills will be able to complete their work on time or set targets, this occurs because employees can dedicate all their abilities in carrying out their duties and be responsible [14] [21]. Workability has a significant effect on employee performance, Workability can be demonstrated by the skills, knowledge, and work experience of employees, by having these three dimensions, employees can achieve higher performance [20], this shows that if Workability is getting better, the performance is better. employees will get better and higher because employee workability has a significant effect on employee performance [17]. H1: Work Ability has a significant effect on employee performance

b. Work ethic

According to [8] the work ethic that should be owned by an employee is the totality of his personality and the way he expresses, views, believes and gives meaning to something, which encourages him to act and achieve optimal charity so that the pattern of relationships between humans with himself and between humans and other creatures can be well established. Employees who have a high work ethic can improve their performance, this is in accordance with the results of research by [15] which states 
that work ethic has a significant effect on employee performance, as well as the results of [20] which states that work ethic has a significant effect on employee performance. [22] said that the work ethic which is defined as a view of the way a person, a group or a nation works, contains a value system that concerns individual perceptions in carrying out their work, and it turns out that the results of his research show that employees who have a good work ethic high also has high performance. H2: Work ethic has a significant effect on employee performance

\section{c. Work environment}

According to [18], the work environment is a place for a number of groups in which there are several supporting facilities to achieve company goals in accordance with the company's vision and mission. Meanwhile, [4] defines the work environment as a source of information and a place to carry out activities, so that a good Working Condition condition must be realized so that employees feel more comfortable and comfortable in the workspace to complete their work, so that a high level of efficiency can be achieved. A comfortable work environment that is in accordance with the type of work will bring employees to perform well, this is in accordance with the results of [14] which states that the work environment has a significant effect on employee performance as well as the results of research by [19] which states that working conditions have a significant effect on employee performance. H3: Work environment has a significant effect on employee performance

d. Employee performance

According to [9], performance is the result of work in quality and quantity achieved by an employee in carrying out his duties in accordance with the responsibilities given to him. Meanwhile, according to [22] performance refers to the level of achievement of the tasks that make up an employee's job. Performance reflects how well an employee fulfills the requirements of a job. Often misinterpreted as effort, which reflects the energy expended, performance is measured in terms of results. Based on the understanding of performance according to some of the experts above, it can be concluded that performance is an embodiment made by employees in improving the work of an employee or organization. Good employee performance is one of the most important factors in the agency's efforts to improve organizational performance. Performance is an indicator in determining how efforts to achieve high performance results in an organization or agency.

Research Result:

From the results of the study, it was found that the respondent's profile consisted of 42 men out of a total of 50 respondents with a percentage value of $84 \%$, then 8 female respondents out of a total of 50 respondents with a percentage value of $16 \%$. 19 employees aged 20-27 years or 38\%, employees aged 28- 35 years as many as 21 people or $42 \%$, and employees aged 36 years as many as 10 people or $20 \%$. The number of employees who work for 1-5 years is 23 people or $46 \%$ of employees who work for $6-10$ years as many as 15 people or $30 \%$, while employees who work for $>11$ years are 12 people or $24 \%$. The number of respondents with junior high school education is 12 people or $24 \%$. Then the number of respondents with high school education as many as 35 people or $70 \%$. Then the number of respondents with S1 education is 3 people or $6 \%$. 
In addition, from the results of respondents' answers as many as 50 respondents showed the frequency of respondents who were married was 27 people with a percentage of $54 \%$. While the frequency of unmarried respondents was 23 people with a percentage of $46 \%$.

Before the regression analysis was carried out, this study analyzed the classical assumption test consisting of the normality test, multicoloniality test, and heteroscedasticity test.

\section{a. Normality test}

Normality test is a test carried out with the aim of assessing the distribution of data in a group of data or variables, whether the distribution of the data is normally distributed or not. Normality test is useful for determining the data that has been collected is normally distributed or taken from a normal population. The normality test in this study can be seen in Figure 1.

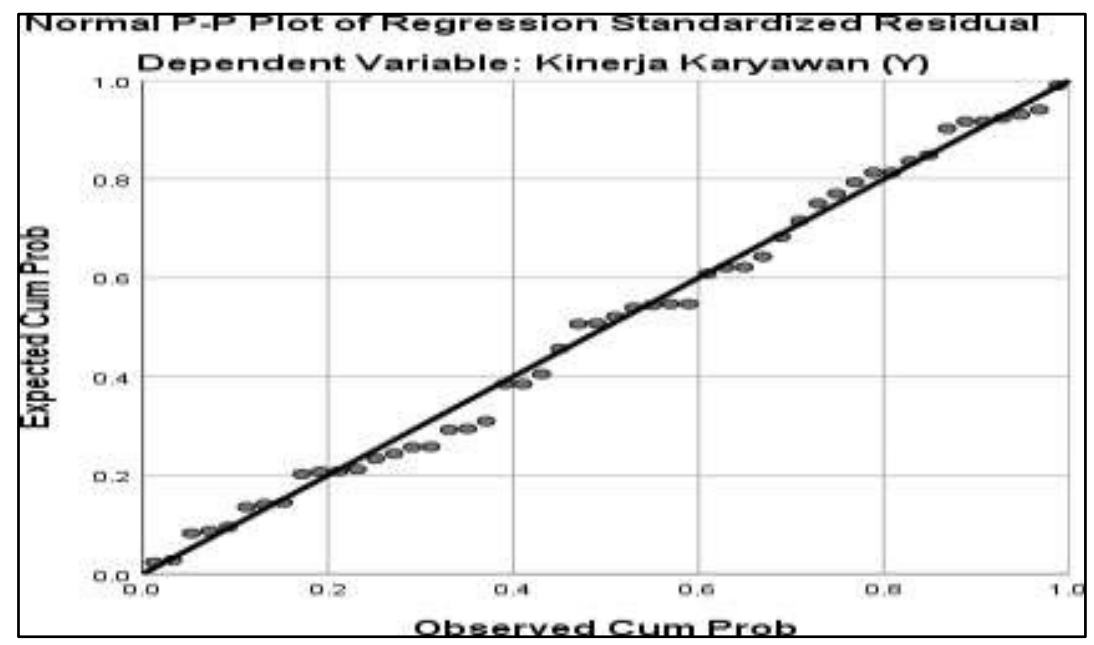

Figure 1. The Result of Normality Test

Based on the normal P-P Plot graph above, it can be seen that the plotting points follow or approach the diagonal line. So it can be concluded that the residual value is normally distributed.

\section{b. Multicolinierity Test}

Multicollinearity test is used to determine whether there are independent variables that have similarities between independent variables in a regression model. If there is a correlation, it is stated that the regression model has multicollinearity problems. Multicolliniarity test in this study can be seen in Tabel 1.

Tabel 1: The Result of Multicolliniarity Test

\begin{tabular}{lcc}
\hline \multicolumn{1}{c}{ Variables } & Tolerance & VIF \\
\hline Work Abilit & 0.122 & 8.184 \\
Work Ethics & 0.361 & 2.769 \\
Working Conditions & 0.167 & 5.992 \\
\hline
\end{tabular}

Table 1 shows that the Work Ability variable has a tolerance value of 0.122 and a VIF value of 8.184, a work ethic variable has a tolerance value of 0.361 and a VIF value 
of 2.769, a Work Environment variable has a tolerance value of 0.167 and a VIF value of 5.992. It can be concluded that the tolerance value $>0.10$ and the VIF value $<10$, then each research variable is considered free from multicollinearity symptoms [7].

c. Heteroscedasticity Test

Heteroscedasticity test was conducted to determine the distribution of the data. Based on the results of the analysis, it can be seen in Figure 3 which shows that the points spread below the number 0 on the $\mathrm{Y}$ axis or do not form a certain pattern. So it is proven that there is no heteroscedasticity.

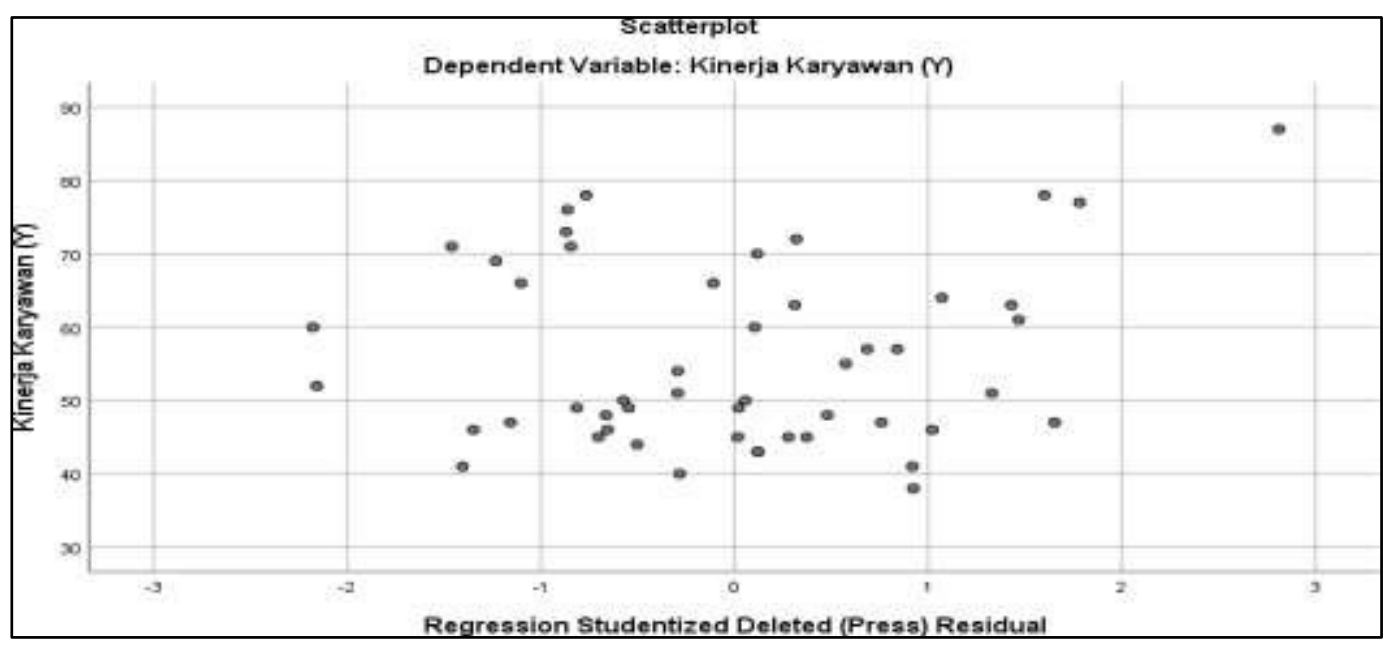

Figure 2. The Result of Heterocedasticity Test

d. Regression Analysis

The purpose of multiple linear regression analysis is to find out how much influence several independent variables have on the dependent variable and can also predict the value of the dependent variable if all the independent variables have known values. The result of Multiple Regression on this study can be seen on table 2 .

Table 2: The Result of Multiple Regression Analysis

\begin{tabular}{|c|c|c|c|c|c|c|}
\hline & \multirow[t]{2}{*}{ Model } & \multicolumn{2}{|c|}{$\begin{array}{l}\text { Unstandardized } \\
\text { Coefficients }\end{array}$} & \multirow{2}{*}{$\begin{array}{c}\begin{array}{c}\text { Standardize d } \\
\text { Coefficients }\end{array} \\
\text { Beta } \\
\end{array}$} & \multirow[t]{2}{*}{$\mathbf{t}$} & \multirow[t]{2}{*}{ Sig } \\
\hline & & B & Std. Error & & & \\
\hline \multirow[t]{4}{*}{1} & (Constant) & -2.493 & 1.170 & & -2.131 & .038 \\
\hline & Work Ability (X1) & .302 & .105 & .143 & 2.875 & .006 \\
\hline & Etos Kerja (X2) & .467 & .068 & .198 & 6.840 & .000 \\
\hline & Lingkungan kerja (X3) & 1.928 & .116 & .706 & 16.564 & .000 \\
\hline
\end{tabular}

Based on the results of the regression analysis calculations in the table, the Multiple Linear Regression equation for this study is obtained:

$$
\mathrm{Y}=-2.493+0.302 \mathrm{~A}+0.467 \mathrm{E}+1.928 \mathrm{~L}+\mathrm{e}
$$

From the results of the multiple linear regression equation in table 2, it can be interpreted as follows: 
The constant of -2.493 has a negative value indicating that if the independent variables Work Ability, Work Ethic, and Work Environment are fixed or constant, then the variation of changes in the dependent variable on employee performance tends to be negative. The coefficient of the Work Ability variable is positive. This means that the Work Ability variable has a positive influence on employee performance with a value of 0.302 assuming the other variables are fixed or constant. The work ethic variable coefficient is positive. This means that the work ethic variable has a positive influence on the employee performance variable, with the acquisition value of 0.467 assuming the other variables are fixed or constant. And the coefficient of the Work Environment variable is positive. This means that the Work Environment variable has a positive influence on employee performance, with the acquisition value of 1,928 assuming the other variables are fixed or constant.

\section{e. Determination Coefficient}

The coefficient of determination is used as information about the suitability of a model and is calculated to determine the extent to which the compatibility of a number of independent variables in a multiple linear regression equation model can simultaneously explain the dependent variable.

Table 3. The Result of Determination Coefficient

\begin{tabular}{lccccr}
\hline Model Summary & & & \\
\hline Model & R & R Square & $\begin{array}{c}\text { Adjusted R } \\
\text { Square }\end{array}$ & $\begin{array}{c}\text { Std. Error of the } \\
\text { Estimate }\end{array}$ & Durbin-Watson \\
\hline 1 & $.993^{a}$ & .986 & .985 & 1.508 & 1.559 \\
& & & & & \\
\hline $\begin{array}{l}\text { a. Predictors: (Constant), Lingkungan kerja (X3), Etos Kerja (X2), Work Ability (X1) } \\
\text { b. Dependent Variable: Kinerja Karyawan (Y) }\end{array}$ & & \\
\hline
\end{tabular}

Table 3 shows the coefficient of determination ( $\mathrm{R}$ square) which is 0.986 . This shows that $98.6 \%$ of the Work Ability, Work Ethic, and Work Environment variables affect the Employee Performance variable. Meanwhile, the remaining $1.4 \%$ is influenced by other variables outside of this study.

Hypothesis test: Hypothesis testing was carried out using the F test to test the effect of the variable work ability, work ethic and work environment on employee performance simultaneously, while the variables were tested using the F-test.

Table 4. F Test Results (Simultaneous Test)

\begin{tabular}{|c|c|c|c|c|c|c|}
\hline \multicolumn{7}{|c|}{ ANOVA $^{a}$} \\
\hline & Model & $\begin{array}{l}\text { Sum of } \\
\text { Squares }\end{array}$ & Df & Mean Square & F & Sig. \\
\hline \multirow[t]{3}{*}{1} & Regression & 7402.629 & 3 & 2467.543 & 1084.624 & $.000^{\mathrm{b}}$ \\
\hline & Residual & 104.651 & 46 & 2.275 & & \\
\hline & Total & 7507.280 & 49 & & & \\
\hline
\end{tabular}

a. Dependent Variable: Kinerja Karyawan (Y)

b. Predictors: (Constant), Lingkungan kerja (X3), Etos Kerja (X2), Work Ability (X1) 
The F-count value is 1084,624 , this value is greater than the f-table, namely 2.81 or the $\mathrm{f}$-count is $1084,624>2.81 \mathrm{f}$-table with a probability value of $0.000<0.05$ so that the regression model can be used to predicting employee performance variables or it can be said that the variables of Work Ability, Work Ethic, and Environment together (simultaneously) have a significant effect on employee job satisfaction.

While the test results with the t-test can be seen in table 5 . Which shows that the Work Ability variable obtains a t-count value of $2.875>2.01$, it is stated that $t$-count $>t$ table. The significance value is $0.006<0.05$. So it can be concluded that the hypothesis (H1) is accepted, meaning that Work Ability has a significant effect on employee performance. The work ethic variable has a t-count value of $6.840>2.01$, so it is stated that $\mathrm{t}$-count $>\mathrm{t}$-table. The significance value is $0.000<0.05$. So it can be concluded that the hypothesis $(\mathrm{H} 2)$ is accepted, meaning that work ethic has a significant effect on employee performance. And the Work Environment Variable obtained a t-count value of $16.564>2.01$, it is stated that $t$-count $>t$-table. The significance value is $0.000<0.05$. So it can be concluded that hypothesis $3(\mathrm{H}-3)$ is accepted, meaning that the work environment has a significant effect on employee performance.

Table 5. T- test Results

\begin{tabular}{|c|c|c|c|c|c|c|}
\hline & \multirow[t]{2}{*}{ Model } & \multicolumn{2}{|c|}{$\begin{array}{l}\text { Unstandardized } \\
\text { Coefficients }\end{array}$} & \multirow{2}{*}{$\begin{array}{c}\begin{array}{c}\text { Standardized } \\
\text { Coefficients }\end{array} \\
\text { Beta }\end{array}$} & \multirow[t]{2}{*}{$\mathbf{t}$} & \multirow[t]{2}{*}{ Sig. } \\
\hline & & B & Std. Error & & & \\
\hline \multirow[t]{4}{*}{1} & (Constant) & -2.493 & 1.170 & & -2.131 & .038 \\
\hline & Work Ability (X1) & .302 & .105 & 143. & 2.875 & .006 \\
\hline & Etos Kerja $(X 2)$ & .467 & .068 & .198 & 6.840 & .000 \\
\hline & Lingkungan kerja (X3) & 1.928 & .116 & .706 & 16.564 & .000 \\
\hline
\end{tabular}

Discussion:

a. The Effect of Work Ability on Employee Performance

Based on the results of the analysis and various tests, the Work Ability variable has a positive and significant effect on the Employee Performance of the Garment Industries. This can be seen from the large significance value, which is $0.006<0.05$, then it is declared positive. In addition, the results of linear regression analysis and regression coefficients which show a value of 0.339 are positive. If the Work Ability variable increases by one unit, then the value of the Employee Performance variable will increase by 0.302 with the assumption that the other independent variables are fixed or constant. The results of this study are also supported by [2] which produces research that work ability has a positive and significant effect on employee performance. The statement of the theoretical concept is in accordance with research conducted [9] which resulted in research that work has a positive and significant effect on employee performance.

b. The Effect of Work Ethic on Employee Performance

Based on the results of the analysis and various tests, the work ethic variable has a positive and significant effect on the employee performance of the Garment Industries. This can be seen from the significant value of $0.000<0.05$, so it is declared positive. In 
addition, the results of linear regression analysis and regression coefficients which show a value of 0.467 are positive. If the work ethic variable increases by one unit, then the value of the Employee Performance variable will increase by 0.467 with the assumption that the other independent variables are fixed or constant. The results of this study are also supported by [11] which resulted in research that work ethic has a positive and significant effect on employee performance. The statement of the theoretical concept is in accordance with research conducted by [17] which results in research that work ethic has a positive and significant effect on employee performance

c. Influence of Work Environment on Employee Performance

Based on the results of the analysis and various tests, the work environment variable has a positive and significant effect on the employee performance of the Garment Industries. This can be seen from the large value of significance is $0.000<0.05$ then it is declared positive. In addition, the results of the linear regression analysis and the regression coefficient which show a value of 1.928 are positive.

If the work environment variable increases by one unit, the value of the Employee Performance variable will increase by 1.928 with the assumption that the other independent variables are fixed or constant. The results of this study are also supported by a study conducted by According to [12] which resulted in research that the work environment had a positive and negative effect. significant to employee performance. The statement of the theoretical concept is in accordance with the research conducted by [22] which resulted in research that the work environment had a positive and significant effect on employee performance.

d. The Influence of Work Ability, Work Ethic and Work Environment on Employee Performance

Based on the research results, Work Ability, Work Ethic, and Work Environment simultaneously have a positive and significant effect on Employee Performance at Garment Industries. It can be seen that the significance value of $F$ is $0.000<0.05$, so this proves that the regression model in this study has a significant positive value and is declared feasible to explain the effect of the variables Work Ability, Work Ethic, and Work Environment on Employee Performance. The calculated F value is 1084,624 while the $\mathrm{F}$ table value $=2.22$ because the calculated $\mathrm{F}$ value is $1084,624>2.81$, as the basis for decision making in the F test, it can be concluded that Ho is rejected and Ha is accepted. These results indicate that work ability, work ethic, and work environment simultaneously affect employee performance.

\section{Conclusion}

Based on the results of research on the effect of work ability, work ethic, and work environment on employee performance at the Garment Industries. So the conclusions in this study are that low Work Ability can reduce the performance of Garment Industries employees in, the lower Work Ability will reduce the performance of Garment Industries employees in and vice versa, A low work ethic can reduce the performance of Garment Industries employees, the lower work ethic will reduce the performance of Garment Industries employees and vice versa. Therefore a low work environment can reduce the performance of the employees of the Garment Industries, 
and the lower the work environment will reduce the performance of the employees of the Garment Industries and vice versa, Lastly Work Ability, work ethic, and work environment as simultaniousely can improve the performance of employees of Garment Industries.

Suggestion: Based on the conclusions above, some suggestions that are expected to be useful for the company and parties involved in this research are as follows:

To improve the performance of the employees of the Garment Industries needs to optimize the indicators of Work ability, Work Ethic and Work Environment by paying attention to the performance of its employees and giving an award for skills, work performance, etc. Because in essence employee performance is very important for the company and can affect the results of employee work.

The GarmentIndustry Jombang needs to pay attention to the work ethic of employees, especially the need to create an atmosphere and conditions that support the improvement of work ethic. In addition, leaders need to seek to provide more budget and develop their employees to be able to improve employee performance. Likewise, the company needs to pay attention to the work environment, this can be done by rearranging so that employees do not feel bored at work.

Further research needs to be done by using other variables outside of independent variables such as compensation and leadership style that affect employee performance where these variables are not examined by the author, but are suspected to have an influence on employee performance.

\section{References}

[1] A. A. Anwar Prabu Mangkunegara. (2013). MSDM. Journal of Chemical Information and Modeling, 53(9), 1689-1699.

[2] Afandi, P. (2018). Manajemen Sumber Daya Manusia (Teori, Konsep dan Indikator). Riau: Zanafa Publishing.

[3] Aliffianto, A. Y., Candraningrat, C., \& Wibowo, J. (2018). Visitor Loyalty Analysis of Marine Tourism in Bayuwangi Beaches. In The 2nd International Conference On Economics And Business (pp. 39-49). STIE Mandala Jember.

[4] Candraningrat, C. (2017). Pengambilan Keputusan sebagai Wirausaha Muda dan Faktor Eksternal yang Mempengaruhinya di Institut Bisnis dan Informatika Stikom Surabaya. Business and Finance Journal, 2(1), 1-14.

[5] Candraningrat, C. (2020). The Effect Of Entrepreneurship Education On Interests Of Entrepreneurship Through Self Awareness In Students In Surabaya. Jmm17, 7.01.

[6] Candraningrat, C., Oktaviani, O., \& Suhandiah, S. (2018). Analysis of the success factors for MSME succession in Surabaya: A principal component analysis. Journal of Economics, Business, and Accountancy Ventura, 21(2), 207-217.

[7] Fianto, A. Y. A., \& Candraningrat, C. (2019). Conceptual Review of Rethinking Marine Tourism Visit Intention from Word of Mouth, Destination Image dan Destination Branding.

[8] Kristiani, A. D., Pradhanawati, A., \& Wijayanto, A. (2013). Pengaruh Kemampuan Kerja Dan Motivasi Kerja Terhadap Kinerja Karyawan (Studi Pada Karyawan 
Operator PT. IndonesiaPower Unit Bisnis Pembangkitan Semarang). Dipenogoro Journal Of Social And Politic, 1-7.

[9] Moulana, F., Sunuharyo, B., \& Utami, H. (2017). Pengaruh Lingkungan Kerja Terhadap Kinerja Karyawan Melalui Variabel Mediator Motivasi Kerja (Studi pada Karyawan

[10] PT. Telkom Indonesia,Tbk Witel Jatim Selatan, Jalan A. Yani, Malang). Jurnal Administrasi Bisnis S1 Universitas Brawijaya, 44(1), 178-185.

[11] Moh. Nazir. (2011). Metode Penelitian. Bogor: Penerbit Ghalia Indonesia

[12] Nurjaya, N., Sunarsi, D., Effendy, A. A., Teriyan, A., \& Gunartin, G. (2021). Pengaruh Etos Kerja Dan Disiplin Kerja Terhadap Kinerja Pegawai Pada Dinas Kehutanan Dan Perkebunan Kota Bogor. JENIUS (Jurnal Ilmiah Manajemen

Sumber Daya Manusia), 4(2), 172.
https://doi.org/10.32493/jjsdm.v4i2.9086

[13] Octarina, A. (2013). Pengaruh Etos Kerja Dan Disiplin Kerja Terhadap Kinerja Pegawai Pada Dinas Kebudayaan Pariwisata Pemuda Dan Olahraga Kabupaten Sarolangun. Manajemen S-1, 1(1), 1-15.

[14] Pamungkas, A., Hamid, D., \& Prasetya, A. (2017). Pengaruh Pendidikan dan Pengalaman Kerja Terhadap Kemampuan Kerja dan Kinerja Karyawan (Studi pada Karyawan PT. INKA (Persero)). Jurnal Administrasi Bisnis S1 Universitas Brawijaya, 43(1), 96-103.

[15] Prakoso, R. (2014). Pengaruh Lingkungan Kerja Terhadap Motivasi Kerja dan Kinerja Karyawan (Studi Pada Karyawan PT. AXA Financial Indonesia Cabang Malang). Jurnal Administrasi Bisnis S1 Universitas Brawijaya, 14(2), 84429.

[16] Siti Mujanah, (2020). Workability and Self Awareness on Employee Engagement in Indonesian Manufacturing Industries, Proceeding International Conference on Business and Banking Innovation (ICOBBI), STIE Perbanas, 14-15 Agustus 2020.

[17] Suratman Hadi. (2019). Pengaruh Lingkungan Kerja Terhadap Kinerja Karyawan (Studi pada Karyawan Kantor Pelayanan Pajak Pratama Malang Utara). Parameter, 4(2), 1-9. https://doi.org/10.37751/parameter.v4i2.41

[18] Sedarmayanti (2017). Perencanaan dan Pengembangan SDM untuk Meningkatkan Kompetensi Kinerja dan Produktivitas Kerja. PT Refika Aditama. Bandung

[18] Sugiyono (2015). Metode Penelitian Kombinasi (Mix Methods). Bandung: Alfabeta.

[19] Sugiyono. (2013). Metode Penelitian Pendidikan Pendekatan Kuantitatif, Kualitatif, dan R\&D. Bandung: Alfabeta.

[20] Sugiyono. (2016). Metode Penelitian Kuantitatif, Kualitatif dan R\&D. Bandung: PT Alfabet.

[21] Suliyanto. (2011). Ekonometrika Terapan: Teori Dan Aplikasi Dengan SPSS. Edisi 1. Yogyakarta: ANDI Yogyakarta

[22] Sinamo, Jansen. (2011). 8 Etos Kerja Profesional. Jakarta: Institut Dharma Mahardika.

[23] Widyanto Eko Susetyo, Amiartuti Kusmaningtyas, dan Hendro Tjahjono, (2014). Pengaruh Budaya Organisasi Dan Lingkungan Kerja Terhadap Kepuasan Kerja Dan Kinerja Karyawan Pada PT. Bank Muamalat Indonesia Divisi Konsumer Area 
Cabang Surabaya, JMM17: Jurnal Ilmu Ekonomi \& Manajemen, Vol. 1 No.1. hal. $83-9383$. 